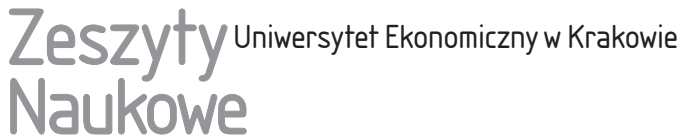

\section{Uzbrojenie terenu i jego wpływ na wartość nieruchomości gruntowej}

\section{Streszczenie}

Celem artykułu jest przedstawienie praktycznego rozwiązania jednego z problemów związanych z oceną projektów inwestycyjnych, jakim jest oszacowanie kosztów infrastruktury inwestycyjnej nieruchomości budowlanej. Omówiono znaczenie infrastruktury użyteczności publicznej dla inwestorów, przytoczono jej definicję i wyszczególniono komponenty (instalacje energetyczne, gazowe i wodne). Zaprezentowano także metodę wyceny projektów inwestycyjnych. Na podstawie aktualnych danych rynkowych przeprowadzono analizę wpływu dostępu do mediów na wartość majątku. W artykule poruszono również temat alternatywnych rozwiązań stosowanych w celu uzyskania na terenie nieruchomości dostępu do instalacji wodociągowych, kanalizacyjnych i gazowych.

Słowa kluczowe: uzbrojenie terenu, ocena projektów inwestycyjnych, wycena nieruchomości, nieruchomość.

Klasyfikacja JEL: G30, R30.

\section{Wprowadzenie}

Teren każdej nieruchomości gruntowej przed rozpoczęciem prac inwestycyjnych musi zostać uzbrojony, co polega na doprowadzeniu w obręb działki sieci wodociągowej, kanalizacyjnej, energetycznej oraz gazowej (Ustawa z dnia 17 maja 
1989 r....). W wypadku każdej, nawet najmniejszej inwestycji musi również zostać zapewniony dostęp do drogi. Zgodnie z prawem na każdej działce budowlanej, przeznaczonej pod budynki, w których będą przebywać ludzie, powinno być możliwe przyłączenie uzbrojenia działki lub bezpośrednio budynku do sieci wodociągowej, kanalizacyjnej, elektroenergetycznej i ciepłowniczej (Rozporządzenie Ministra Infrastruktury z dnia 12 kwietnia 2002 r....).

Podstawowym celem artykułu jest określenie wpływu uzbrojenia terenu na wartość nieruchomości gruntowej. W opracowaniu omówiono elementy zaliczane do sieci uzbrojenia terenu oraz poddano analizie koszty przyłączenia do sieci, jakie musi ponieść inwestor. Poruszono również kwestię alternatywnych sposobów podłączenia instalacji wodnej, kanalizacyjnej oraz gazowej. Zagadnienie dostępu nieruchomości do podstawowych sieci uzbrojenia terenu nie jest opisywane w literaturze przedmiotu, dlatego zdecydowano o podjęciu tego istotnego tematu. Dane poddane analizie zostały zebrane $\mathrm{w}$ wywiadzie środowiskowym, korzystano także $\mathrm{z}$ informacji publikowanych $\mathrm{w}$ literaturze branżowej.

\section{Uzbrojenie terenu}

Na rynku nieruchomości w Polsce wyróżnia się dwa typy nieruchomości budowlanych: nieruchomości budowlane uzbrojone oraz nieuzbrojone (Prystupa 2016). W wypadku nieruchomości budowlanej uzbrojonej zostały zawarte umowy z dostawcami mediów, czyli zostało zainstalowane przyłącze prądu, gazu, wody oraz ewentualnie przyłącze kanalizacyjne, w wypadku natomiast nieruchomości budowlanej nieuzbrojonej umowy takie nie zostały zawarte, ale może się ona znajdować w bezpośrednim obrębie i bliskości mediów lub mieć do nich pośredni dostęp. Informacje o tym, czy dana nieruchomość budowlana jest uzbrojona, czy też nie, można znaleźć na mapie zasadniczej, do której dostęp uzyskuje się w urzędzie miasta lub gminy w wydziale kartografii i geodezji. Gdy dana nieruchomość nie jest uzbrojona, inwestor powinien udać się bezpośrednio do instytucji dostarczających wodę, gaz oraz energię elektryczną, a następnie wystąpić o wydanie warunków technicznych doprowadzenia danego przyłącza przez dostawcę mediów (Buśko i Przewięźlikowska 2011). Procedura uzbrojenia terenu wiąże się z koniecznością przekazania każdemu z dostawców mediów dokumentów, takich jak: akt własności nieruchomości, mapy zasadnicze lub mapy do celów projektowych (w zależności od dostawcy mediów) oraz wypis z rejestru gruntów. Następnie na mocy umowy z dostawcami mediów inwestor jest zobowiązany do dokonania opłaty przyłączeniowej, ustalonej przez właściwego ministra, za którą dany dostawca mediów ma obowiązek wykonania przyłączy na granicy nieruchomości - w wypadku sieci gazowej i energetycznej instaluje skrzynki, 
od których inwestor samodzielnie wykonuje przyłącza do budynku, prowadząc tzw. wewnętrzną linię zasilającą.

\section{Koszty ponoszone przez inwestora w związku z uzbrojeniem terenu}

Wydanie warunków przyłączeniowych jest bezpłatne, lecz wykonanie przyłączy wiąże się z koniecznością poniesienia przez przedsiębiorcę sporych kosztów. Zasady wykonywania przyłączy poszczególnych mediów oraz opłaty w tym zakresie są różne w poszczególnych regionach Polski, zależą od tego, kto jest właścicielem sieci. W tabeli 1 zaprezentowano dane dotyczące kosztów budowy przyłącza $1 \mathrm{~kW}$ sieci energetycznej w wypadku korzystania z usług danego dostawcy energii.

Tabela 1. Koszt wykonania przyłącza $1 \mathrm{~kW}$ w zależności od operatora (w zł)

\begin{tabular}{|l|c|c|}
\hline \multirow{2}{*}{ Wyszczególnienie } & \multicolumn{2}{|c|}{ Stawki dla odbiorców z IV, V i VI grupy } \\
\cline { 2 - 3 } & przyłącze napowietrzne & przyłącze kablowe \\
\hline RWE & 39,37 & 62,23 \\
\hline PGE & 43,73 & 59,37 \\
\hline Energa & 43,78 & 59,23 \\
\hline Tauron & 44,91 & 61,60 \\
\hline Enea & 45,41 & 65,79 \\
\hline $\begin{array}{l}\text { Każdy metr powyżej 200 m } \\
\text { (wartość uśredniona) }\end{array}$ & 24,87 & 33,20 \\
\hline
\end{tabular}

Źródło: opracowanie własne na podstawie danych zakładów energetycznych z 2017 r.

W wypadku sieci energetycznej koszt przyłącza napowietrznego wynosi 39,37-45,41 zł za każdy $1 \mathrm{~kW}$ przydzielonej mocy. Gdy inwestor zdecyduje się na przyłącze kablowe podziemne, cena wzrasta do ok. 60 zł za każdy 1 kW. Jeśli przyłącze ma ponad $200 \mathrm{~m}$, inwestor jest zobowiązany do zapłacenia ok. $30 \mathrm{zł}$ za każdy dodatkowy metr. Opłata ta obejmuje całość prac związanych z budową przyłącza, w tym najbardziej kosztowne prace projektowe, a także kupno i montaż złączy, licznika, obudowy oraz innych niezbędnych podzespołów. Standardowa moc przyłącza dla inwestycji wynosi $15 \mathrm{~kW}$, wykonanie całej instalacji kosztuje zatem 1500-2700 zł. Ostateczną cenę wykonania przyłącza ustala dostawca energii elektrycznej. Z uwagi na to, że długość przyłączy często przekracza $200 \mathrm{~m}$, faktyczny koszt inwestycji jest zwykle kilkukrotnie wyższy. 
Podobna sytuacja występuje w wypadku wykonywania przyłącza sieci gazowej. Jeżeli w gminnych założeniach dotyczących zaopatrzenia w ciepło, energię elektryczną i paliwa gazowe została zaplanowana rozbudowa lub budowa sieci gazowej, lokalny operator ma obowiązek stosowania stawek określonych w taryfie ujętej w planie. Opłata za przyłączenie do sieci gazowej jest wówczas zryczałtowana, a zakład ma obowiązek sporządzenia projektu przyłącza gazowego, który powinien być wykonany przez jednostkę posiadającą uprawnienia do projektowania instalacji wewnętrznych i zewnętrznych obejmujące projektowanie instalacji gazowych, potwierdzone wpisem do rejestru prowadzonego przez zakład gazowniczy. Projekt jest uzgadniany, a następnie wykonawca przyłącza zgłasza w starostwie budowę lub rozbudowę. Na operatorze sieci gazowniczej spoczywa także obowiązek budowy przyłącza oraz sporządzenia pełnej dokumentacji w tym zakresie, a także przekazania inwestycji do odbioru przez odpowiednich specjalistów. Wysokość opłaty zależy od średnicy i długości przyłącza oraz użytych materiałów i technologii wykonania. Każdy operator sieci gazowniczej ustala swoje stawki, które są określane z uwzględnieniem standardowych warunków. Jeśli przyłącze musi zostać zbudowane w inny sposób, wynikający ze specyficznych warunków, opłata zostaje ustalona na podstawie rzeczywistych kosztów, zgodnie z zapisami zawartymi w umowie o przyłączenie.

Koszty wykonania przyłączy sieci gazowej, podobnie jak sieci energetycznej, są różne w poszczególnych regionach kraju. W tabeli 2 przedstawiono dane dotyczące kosztów wykonania przyłącza instalacji gazowej w danym regionie kraju, uzyskane z dokumentacji spółki Skarbu Państwa Polskie Górnictwo Naftowe i Gazownictwo (PGNiG).

Tabela 2. Koszt budowy przyłącza gazowego w poszczególnych regionach (w zł/m)

\begin{tabular}{|l|c|c|}
\hline \multicolumn{1}{|c|}{ Wyszczególnienie } & $\begin{array}{c}\text { Opłata ryczałtowa za budowę } \\
\text { przyłącza o długości do 15 m }\end{array}$ & $\begin{array}{c}\text { Stawka opłaty za każdy metr } \\
\text { przyłącza powyżej 15 m }\end{array}$ \\
\hline $\begin{array}{l}\text { Na obszarze działania } \\
\text { oddziału w Gdańsku }\end{array}$ & 1942,20 & 79,7 \\
\hline $\begin{array}{l}\text { Na obszarze działania } \\
\text { oddziału w Poznaniu }\end{array}$ & 1847,00 & 70,2 \\
\hline $\begin{array}{l}\text { Na obszarze działania } \\
\text { oddziału w Tarnowie }\end{array}$ & 1754,70 & 78,5 \\
\hline $\begin{array}{l}\text { Na obszarze działania } \\
\text { oddziału w Warszawie }\end{array}$ & 1932,00 & 77,8 \\
\hline $\begin{array}{l}\text { Na obszarze działania } \\
\text { oddziału we Wrocławiu }\end{array}$ & 1920,20 & 71,8 \\
\hline $\begin{array}{l}\text { Na obszarze działania } \\
\text { oddziału w Zabrzu }\end{array}$ & 1837,60 & \\
\hline
\end{tabular}

Źródło: opracowanie własne na podstawie danych uzyskanych od operatora sieci gazowej. 
Jak wynika $\mathrm{z}$ danych zamieszczonych w tabeli 2, mimo że operatorem na terenie całego kraju jest spółka PGNiG, opłaty za przyłącza gazowe są zróżnicowane: 1754,70-1932 zł. Oznacza to, że różnica cen wynosi prawie 10\%. Stawki za wykonanie przyłącza dłuższego niż $15 \mathrm{~m}$ także są zróżnicowane, a różnica cen obowiązujących w najtańszym i najdroższym oddziale PGNiG wynosi 17 zł za każdy dodatkowy metr inwestycji.

Kolejnym elementem niezbędnym do uzbrojenia terenu jest uzyskanie warunków wodno-kanalizacyjnych (Bolt i in. 2012). Podobnie jak w wypadku przyłączy energetycznych i gazowych stawki za wykonanie przyłączy wodno-kanalizacyjnych także zależą od regionu i lokalnego operatora. W tabeli 3 zestawiono informacje dotyczące kosztów wykonania przyłączy wodno-kanalizacyjnych.

Tabela 3. Koszt budowy przyłącza wodociągowo-kanalizacyjnego w zależności od regionu

\begin{tabular}{|l|c|}
\hline \multicolumn{1}{|c|}{ Wyszczególnienie } & Stawka opłat (w zł) \\
\hline Wydanie warunków wykonania przyłącza wodno-kanalizacyjnego & $120-160$ \\
\hline Projekt przyłącza wodnego bądź kanalizacyjnego & $1300-2600$ \\
\hline Uzgodnienie projektu (Zespół Uzgodnień Dokumentacji Projektowej) & $40-60$ \\
\hline Uzgodnienie projektu (przedsiębiorstwo wodno-kanalizacyjne) & $100-150$ \\
\hline Projekt zmian w ruchu drogowym oraz zajęcie pasa & $500-900$ \\
\hline Opłaty geodezyjne (wykonanie map, wytyczenie przebiegu przyłączy) & $800-1200$ \\
\hline Geodezyjna inwentaryzacja powykonawcza & $300-700$ \\
\hline Odbiór końcowy przyłącza & $100-150$ \\
\hline Opłata przyłączeniowa & $1200-2000$ \\
\hline Koszt budowy w wypadku instalacji kanalizacyjnej & $60-180$ (za mb.) \\
\hline Koszt budowy w wypadku instalacji wodociągowej & $60-100$ (za mb.) \\
\hline
\end{tabular}

Źródło: opracowanie własne na podstawie danych opublikowanych w portalu kb.pl oraz analizy cenników dostawców usług wodno-kanalizacyjnych.

Jak wynika $z$ danych przedstawionych w tabeli 3, opłaty za budowę przyłącza wodno-kanalizacyjnego są zdecydowanie wyższe od tych za przyłącza gazowe oraz energetyczne. Bardzo duży wpływ na ostateczny koszt przedsięwzięcia ma długość odcinka budowanej instalacji oraz skomplikowana procedura zaprojektowania i zatwierdzenia jej przebiegu.

W zdecydowanej większości przypadków zarówno instalacje wodociągowe, jak i kanalizacyjne stanowią wyłączną własność gminy. W związku z tym wykonanie tych przyłączy odbywa się na warunkach ustalonych przez lokalnego dostawcę mediów. Operator zarządzający siecią pokrywa wydatki związane z jej rozbudową, koszty budowy przyłączy ponosi jednak inwestor. Instalacja kanalizacyjna 
i wodociągowa nie należy do inwestora - po wykonaniu oraz odbiorze przyłącza wodnego i kanalizacyjnego inwestor musi przekazać je dostawcy usług. Zasady odbioru przyłączy są określone w umowie i nie wiążą się z żadnymi kosztami ani profitami dla inwestora. Od chwili przekazania przyłączy przez inwestora za stan i eksploatację danego przyłącza jest odpowiedzialny operator usług wodno-kanalizacyjnych.

Terminy wykonania przyłączy zależą od regionu, w którym prowadzona jest inwestycja. Jak wynika $\mathrm{z}$ danych publikowanych na stronach internetowych operatorów odpowiedzialnych za wykonanie i obsługę przyłączy mediów, średni czas oczekiwania na przyłącze energii elektrycznej wynosi 6-9 miesięcy. Zdecydowanie krótszy jest okres oczekiwania inwestorów na wykonanie przyłączy instalacji gazowej: średni czas wykonania takiej usługi wynosi 7-21 dni. Podobny jest okres oczekiwania na doprowadzenie przyłączy wodno-kanalizacyjnych: nie powinien być dłuższy niż 9-16 dni. Należy zaznaczyć, że podane terminy dotyczą realizacji inwestycji w miejscach, w których nie ma konieczności projektowania i budowy nowej infrastruktury, czyli zakres prac ogranicza się do podpięcia przyłącza do istniejącej instalacji. Jeśli w obrębie danej nieruchomości nie ma infrastruktury umożliwiającej podpięcie do instalacji nowej inwestycji, czas wykonania takiego przyłącza może być o wiele dłuższy, co wiąże się ze wzrostem kosztów, którymi w większości obciążony jest inwestor.

\section{Alternatywne sposoby uzyskania dostępu do instalacji wodnej, kanalizacyjnej oraz gazowej}

O ile możliwość przyłączenia danej działki do sieci energetycznej jest w Polsce warunkiem koniecznym do uzyskania pozwolenia na budowę, o tyle w wypadku sieci wodociągowo-kanalizacyjnej oraz gazowej dopuszcza się zastosowanie alternatywnych rozwiązań: korzystanie z indywidualnego ujęcia wody oraz zastosowanie zbiornika bezodpływowego lub przydomowej oczyszczalni ścieków (jeżeli ilość ścieków nie przekracza $5 \mathrm{~m}^{3}$ na dobę, jeśli natomiast jest ich więcej, to ich gromadzenie lub oczyszczanie wymaga zgody terenowego inspektora ochrony środowiska). Jeśli nie ma możliwości doprowadzenia sieci gazowej, można zainstalować zbiornik na gaz płynny lub olej opałowy. W razie braku możliwości podłączenia do sieci wodociągowej jedynym rozwiązaniem jest wykopanie i użytkowanie studni głębinowej, gdy problemem jest uzyskanie dostępu do instalacji kanalizacyjnej, rozwiązań jest więcej.

Do niedawna jedynym wyjściem w wypadku braku kanalizacji było korzystanie z przydomowego szamba. Jest to jedyne rozwiązanie w sytuacji, gdy warunki nie pozwalają na odprowadzanie oczyszczonych ścieków do gruntu czy 
rzeki. Jest ono również stosowane, gdy ścieków jest na tyle mało, że nie opłaca się budować przydomowej oczyszczalni albo trudno zapewnić jej właściwe działanie. Szambo musi być szczelne - tylko jeśli warunek ten jest spełniony, nie stanowi ono zagrożenia dla środowiska, a w szczególności dla czystości wód podziemnych. Zgodnie z przepisami szambo powinno być oddalone o minimum $5 \mathrm{~m}$ od okien i drzwi budynku mieszkalnego, $15 \mathrm{~m}$ od studni oraz 7,5 m od granicy działki, drogi czy chodnika. Odległości te można zmniejszać do 5 i $2 \mathrm{~m}$, ale tylko na terenie zabudowy jednorodzinnej, za zgodą urzędu gminy, która musi być wydana w porozumieniu z wojewódzkim inspektoratem sanitarnym.

Alternatywnym rozwiązaniem jest utworzenie przydomowej oczyszczalni ścieków. Budowa i użytkowanie przydomowej oczyszczalni ścieków wiąże się jednak z pewnymi ograniczeniami. Jednym z wymogów jest odpowiednia wielkość działki - przydomowe oczyszczalnie ścieków można budować tylko na działkach, na których minimalna odległość zbiornika wstępnego oczyszczania od studni głębinowej wynosi przynajmniej $15 \mathrm{~m}$, a w ciągu drenów rozsączających odległość ta nie może być mniejsza niż $30 \mathrm{~m}$. W wypadku budowy oczyszczalni, w której zostanie zastosowane powierzchniowe złoże filtracyjne, odległość ta musi wynosić minimum $70 \mathrm{~m}$. Jak wynika z informacji uzyskanych na podstawie wywiadu środowiskowego przeprowadzonego z właścicielami firm świadczących usługi montażu urządzeń kanalizacyjnych w województwie małopolskim, w czerwcu 2017 r. koszt budowy szamba wynosił ok. 5000 zł, a budowa oczyszczalni stanowiła wydatek rzędu 7500-15 000 zł. Roczne koszty eksploatacyjne w wypadku szamba to 2500-3000 zł - znacznie więcej niż koszty eksploatacji przydomowych oczyszczalni ścieków, które wynoszą ok. 600 zł. Jeśli więc warunki pozwalają na zainstalowanie przydomowej oczyszczalni ścieków, jest to rozwiązanie bardziej opłacalne.

Gdy w miejscu inwestycji nie jest możliwe przyłączenie instalacji gazowej, specjaliści zalecają zastosowanie: energii elektrycznej, pomp ciepła, paliw stałych lub gazu płynnego. Korzystanie z energii elektrycznej wiąże się z wysokimi kosztami instalacyjnymi, jak również wysokimi kosztami eksploatacyjnymi w późniejszym okresie. System ogrzewania oparty na zastosowaniu tradycyjnych grzejników konwekcyjnych kosztuje kilka tysięcy złotych, a zainstalowanie podłogowego ogrzewania elektrycznego - nawet kilkanaście tysięcy złotych.

Drugie rozwiązanie dostępne na rynku polega na zastosowaniu tzw. pomp ciepła. Wydatki inwestycyjne w tym wypadku są jednak wyższe niż te związane $\mathrm{z}$ instalacją centralnego ogrzewania $\mathrm{z}$ kotłem. Instalacja pompy ciepła z wymiennikiem gruntowym kosztuje ponad 50 tys. zł. Istotną zaletą tej metody jest jej bezobsługowość i bardzo wysoka efektywność. Dzięki zastosowaniu pompy ciepła prawie $75 \%$ energii niezbędnej do ogrzewania domu pozyskuje się bezpośrednio $\mathrm{z}$ gruntu. 
Innym rozwiązaniem problemu braku dostępu do instalacji gazowej jest użycie paliw stałych. Do najczęściej stosowanych paliw stałych należy węgiel, który jest jednym z najbardziej wysokoemisyjnych paliw energetycznych. Jak wynika z analizy cenników jednostek zajmujących się sprzedażą i dystrybucją kotłów węglowych, koszt zakupu takiego urządzenia wraz z zasobnikiem na ciepłą wodę wynosi 9000-12 000 zł. Mimo że większość urządzeń jest wyposażona w zasobnik na węgiel wraz z podajnikiem, to ich obsługa jest bardzo czasochłonna. Największym problemem związanym z zastosowaniem tego rozwiązania jest to, że uruchamianie systemu grzewczego jest konieczne także w miesiącach letnich, umożliwia bowiem uzyskanie dostępu do ciepłej wody, choć można wówczas korzystać z podgrzewaczy elektrycznych.

Ostatnią z omawianych możliwości w wypadku braku instalacji gazowej jest zastosowanie gazu płynnego. Wybór tej metody jest rozwiązaniem coraz częściej stosowanym przez inwestorów ze względu na stosunkowo niskie koszty przyłącza, jak również dostępność i cenę zbiornika gazowego. Nie bez znaczenia jest także to, że gaz płynny w odróżnieniu od oleju opałowego może być również stosowany do gotowania. Ważne jest także to, że w wypadku pojawienia się możliwości zbudowania przyłącza gazu ziemnego inwestor posiadający instalację na gaz płynny wraz z nowoczesnym kotłem i centralnym ogrzewaniem nie musi zmieniać urządzeń. Jedyną konieczną do wprowadzenia zmianą jest wówczas wymiana dysz w palniku kotła i późniejsza regulacja urządzeń.

\section{Wpływ uzbrojenia terenu na wartość gruntu}

W ustawie o gospodarce nieruchomościami (Ustawa z dnia 21 sierpnia 1997 r...) oraz w standardach zawodowych rzeczoznawców majątkowych wartość rynkową nieruchomości zdefiniowano jako najbardziej prawdopodobną cenę możliwą do uzyskania na rynku nieruchomości przy jednoczesnym przyjęciu założeń umożliwiających otrzymanie właśnie takiej ceny. Wartość rynkowa nieruchomości odzwierciedla stan rynku w dniu, w którym została określona, i odpowiada cenie, jaką można by uzyskać, zawierając umowę sprzedaży.

Uzbrojenie terenu jest istotnym elementem wpływającym na wartość nieruchomości. Jak wynika z danych opublikowanych przez firmę Real Experts, zrzeszającą rzeczoznawców majątkowych, uzbrojenie terenu jest drugą po lokalizacji istotną cechą mającą wpływ na cenę nieruchomości gruntowej. W tych samych badaniach dowiedziono, że ceny transakcyjne działek uzbrojonych są średnio o 30-40\% wyższe niż terenów nieuzbrojonych. Podobne wyniki uzyskano, analizując dane dostępne w portalu działki.pl oraz otodom.pl. $Z$ analizy dostępnych ofert wynika, że średnie ceny transakcyjne działek uzbrojonych zlokalizowanych w wybranych gminach małopolski są wyższe o 15-40\% od gruntów nieuzbrojonych. 
Tereny z dostępem do mediów lub mediami doprowadzonymi na działkę są zdecydowanie droższe. Inwestor decydujący się na zakup gruntów nieuzbrojonych musi jednak uwzględnić konieczność poniesienia kosztów doprowadzenia przyłączy mediów.

Jak napisano we wcześniejszej części opracowania, o ile zastąpienie kanalizacji i instalacji gazowej innymi rozwiązaniami jest możliwe, o tyle doprowadzenie przyłącza energii elektrycznej jest warunkiem koniecznym do ubiegania się o pozwolenie na budowę. Należy pamiętać, że jeśli działka nie jest uzbrojona, wiele formalności wymaganych do uzyskania przyłączy musi przeprowadzić inwestor, a koszty dociągnięcia mediów mogą być bardzo wysokie. Ważne jest więc, aby warunki przyłączenia mediów poznać jeszcze przed zakupem działki, żeby w ostatecznej kalkulacji w cenie działki zostały uwzględnione koszty doprowadzenia wszystkich mediów. Pomoże to inwestorowi uniknąć sytuacji, w której okazałoby się, że koszty budowy przyłączy zwielokrotniają nakłady inwestycyjne.

W Polsce na podstawie przepisów ustawy jest prowadzona Geodezyjna Ewidencja Sieci Uzbrojenia Terenu (Ustawa z dnia 17 maja 1989 r....). Jest to rejestr publiczny, w którym są gromadzone, aktualizowane i udostępniane informacje o sieciach uzbrojenia terenu. Prowadzenie i aktualizowanie tej bazy jest zadaniem starostów (prezydentów miast na prawach powiatu). Można w niej znaleźć informacje o projektowanych, budowanych oraz istniejących sieciach uzbrojenia terenu, ich usytuowaniu, przeznaczeniu oraz podstawowych parametrach technicznych, a także o podmiotach, do których należą te sieci. Zakres danych gromadzonych w powiatowej Geodezyjnej Ewidencji Sieci Uzbrojenia Terenu, tryb i standardy tworzenia i aktualizacji baz oraz udostępniania danych są regulowane zapisami rozporządzenia (Rozporządzenie Ministra Administracji i Cyfryzacji z dnia 21 października 2015 r....). Posiadając dane na temat numeru, obrębu oraz lokalizacji działki, inwestor ma możliwość sprawdzenia nie tylko rozlokowania sieci energetycznych, gazowych, wodnych i kanalizacyjnych, lecz także uzyskania informacji o znajdujących się na danym terenie:

- przewodach (benzynowych, ciepłowniczych, elektroenergetycznych, gazowych, kanalizacyjnych, naftowych, telekomunikacyjnych, wodociągowych i in.),

- obudowach przewodów,

- budowlach podziemnych,

- urządzeniach technicznych związanych z siecią,

- punktach o określonej wysokości,

- słupach i masztach,

- korytarzach przesyłowych.

Powiatowe bazy Geodezyjnej Ewidencji Sieci Uzbrojenia Terenu mają zostać połączone w jedną wspólną krajową bazę danych geodezyjnych. Zrealizowanie tego projektu wymaga poniesienia nakładów finansowych przekraczających 
$87 \mathrm{mln}$ zł. Dzięki temu zostaną zgromadzone i udostępnione informacje o przestrzennym rozkładzie sieci uzbrojenia terenu pochodzące z lokalnych baz danych, istotne m.in. w inwentaryzacji i ewidencji sieci ciepłowniczych, kanalizacyjnych, telekomunikacyjnych, wodociągowych, gazowych, elektroenergetycznych oraz w przygotowywaniu planów zagospodarowania przestrzennego. Krajowa Geodezyjna Ewidencja Sieci Uzbrojenia Terenu będzie służyć obywatelom, przedsiębiorcom oraz podmiotom administracji publicznej (Jagielski 2016).

Należy również rozpatrzyć, czy doprowadzenie mediów na koszt inwestora pozwoli mu uzyskać większe przychody w momencie sprzedaży takiej nieruchomości niż sprzedaż terenu nieuzbrojonego. W zdecydowanej większości przypadków takie rozwiązanie powinno zwiększyć przychody inwestora, może się jednak zdarzyć, że z uwagi na wysokie koszty uzbrojenia terenu wydatki w znacznym stopniu przewyższą możliwe do uzyskania przychody ze sprzedaży danej nieruchomości gruntowej. Przed podjęciem decyzji o doprowadzeniu przyłączy mediów do nieruchomości gruntowych inwestor powinien więc przeprowadzić szczegółową analizę kosztów i zysków związanych z takim przedsięwzięciem z uwzględnieniem różnic cen terenów uzbrojonych i nieuzbrojonych. Tylko dokładna i rzetelna analiza pozwoli jednoznacznie stwierdzić, czy doprowadzenie mediów do nieruchomości gruntowej należącej do inwestora przyczyni się do uzyskania realnych korzyści w momencie sprzedaży.

\section{Zakończenie}

Zagadnienia dotyczące sieci uzbrojenia terenu powinny być analizowane podczas podejmowania decyzji inwestycyjnych. Dostęp do podstawowych mediów jest czynnikiem decydującym o usytuowaniu danej inwestycji w konkretnej lokalizacji. Sieć uzbrojenia terenu z roku na rok jest coraz bardziej rozbudowana, mimo to nawet w bardzo dobrych lokalizacjach nadal występują tereny pozbawione dostępu do kanalizacji lub sieci gazowej. Wówczas inwestor powinien przeprowadzić analizę umożliwiającą stwierdzenie, czy inwestycja przeprowadzana w danej lokalizacji będzie opłacalna.

\section{Literatura}

Bolt A., Gudelis-Taraszkiewicz K., Suligowski Z., Tuszyńska A. (2012), Kanalizacja projektowanie, wykonanie, eksploatacja, Wydawnictwo Seidel-Przywecki sp. z o.o., Piaseczno.

Buśko M., Przewięźlikowska A. (2011), Analiza zróżnicowania nazewnictwa elementów uzbrojenia terenu $w$ ujęciu branżowym na przykładzie osiedla domów jednorodzinnych, ,Infrastruktura i Ekologia Terenów Wiejskich”, nr 4. 
Jagielski A. (2016), Podstawy geodezji inżynieryjnej cz. 2. Pomiary: miejskie, inwentaryzacyjne, sieci uzbrojenia, przemieszczeń $i$ odksztatceń, Wydawnictwo Geodpis, Kraków.

Prystupa M. (2016), Wycena nieruchomości i przedsiębiorstw w podejściu dochodowym, Wydawnictwo Frel, Warszawa.

Rozporządzenie Ministra Administracji i Cyfryzacji z dnia 21 października 2015 r. w sprawie powiatowej bazy GESUT i krajowej bazy GESUT, Dz.U. poz. 1938.

Rozporządzenie Ministra Infrastruktury z dnia 12 kwietnia 2002 r. w sprawie warunków technicznych, jakim powinny odpowiadać budynki i ich usytuowanie, Dz.U.2015.0.1422.

Ustawa z dnia 17 maja 1989 r. Prawo geodezyjne i kartograficzne, Dz.U. 2017, poz. 2101.

Ustawa o gospodarce nieruchomościami z dnia 21 sierpnia 1997 r., Dz.U. 2004, nr 261, poz. 2603, ze zm.

\section{Utility Networks and their Impact on the Value of Land}

(Abstract)

The article presents a practical solution to a problem in appraising investment projects cost estimation of the construction investment utility infrastructure. In particular, it defines utility infrastructure for investors and its components (energy, gas and water supply installations), explains its importance, presents a valuation method, and based on current market data shows the impact of utilities on the value of real estate. The article also looks at alternative ways of supplying water, sewage and gas installations to real estate.

Keywords: utility infrastructure, investment projects appraisal, property valuation, property. 